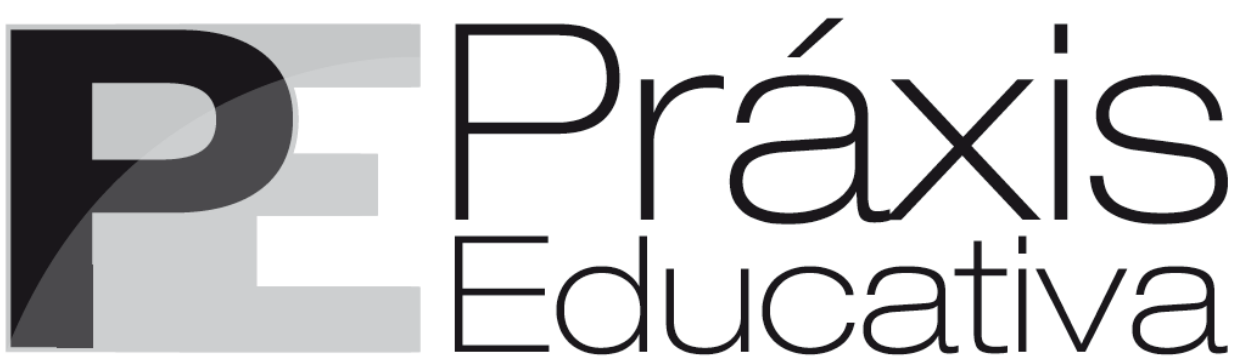

ISSN 1809-4031

elSSN 1809-4309

https://doi.org/10.5212/PraxEduc.v15.14343.018

\title{
Arranjos de Desenvolvimento da Educação (ADEs) como estratégia de atuação do setor privado na educação pública
}

\section{Arrangements of Education Development (ADEs) as a private sector strategy for public education}

\section{Ajustes de Desarrollo de la Educación (ADEs) como estrategia de actuación del sector privado en la educación pública}

Elma Júlia Gonçalves de Carvalho*

iD https://orcid.org/0000-0003-4770-4649

Vera Maria Vidal Peroni**

iD https://orcid.org/0000-0001-6543-8431

Resumo: Neste artigo, apresentam-se reflexões sobre os Arranjos de Desenvolvimento da Educação (ADEs), elaborados em meio à busca por novas formas de coordenação e de cooperação entre os entes federados para a construção de um Sistema Nacional de Educação e para a melhoria na qualidade da educação. A análise aponta que os ADEs vêm se configurando como uma estratégia nas relações intergovernamentais, a qual envolve o associativismo territorial, a colaboração horizontal, o trabalho em rede entre municípios com proximidade geográfica e características sociais e econômicas semelhantes e a realização de acordos de cooperação e parcerias com órgãos públicos e instituições privadas e nãogovernamentais. Os resultados indicam que a construção desse novo modelo de cooperação como espaço de atuação do setor privado na estrutura estatal, com ou sem fins lucrativos, tem implicações para a democratização da educação.

Palavras-chave: Arranjos de Desenvolvimento da Educação. Regime de Colaboração. Parceria públicoprivada.

Abstract: In this article, we present reflections on the Arrangements of Education Development (ADEs, the acronym in Portuguese) elaborated in the search for new forms of coordination and cooperation among the federal entities for the construction of a National Education System and for the improvement in the quality of education. The analysis points out that the ADEs are becoming an strategy in intergovernmental

\footnotetext{
* Professora da Universidade Estadual de Maringá (UEM). Doutora em Educação pela Universidade Metodista de Piracicaba (UNIMEP). E-mail: <elmajulia@hotmail.com>.

** Professora da Universidade Federal do Rio Grande do Sul (UFRGS). Doutora em Educação pela Pontifícia Universidade Católica de São Paulo (PUC-São Paulo). Bolsista de Produtividade em Pesquisa- CNPq. E-mail: <veraperoni@gmail.com>.
} 
Arranjos de Desenvolvimento da Educação (ADEs) como estratégia de atuação do setor privado...

relations, which involves territorial associativism, horizontal collaboration, networking among municipalities with similar geographic, social and economic characteristics, and the establishment of cooperation agreements and partnerships with public, private and non-governmental institutions. The results indicate that the construction of this new model of cooperation as a space for the private sector in the State structure, whether for profit or not, has implications for the democratization of education.

Keywords: Arrangements for the Development of Education. Collaborative arrangements. Public-private partnership.

Resumen: En este artículo, se presentan reflexiones sobre los Ajustes de Desarrollo de la Educación (ADEs), elaborados en medio a la búsqueda por nuevas formas de coordinación y de cooperación entre los entes federados para la construcción de un Sistema Nacional de Educación y para la mejoría en la calidad de la educación. El análisis apunta que los ADEs vienen configurándose como una estrategia en las relaciones intergubernamentales, el cual envuelve al asociativismo territorial, a la colaboración horizontal, el trabajo en red entre municipios con proximidad geográfica y características sociales y económicas semejantes, y la realización de acuerdos de cooperación y alianzas con órganos públicos e instituciones privadas y no gubernamentales. Los resultados indican que la construcción de ese nuevo modelo de cooperación como espacio de actuación del sector privado en la estructura estatal, con o sin fines de lucro, tiene implicaciones para la democratización de la educación.

Palabras clave: Ajustes de Desarrollo de la Educación. Régimen de colaboración. Alianza público-privada.

\section{Introdução}

Os Arranjos de Desenvolvimento da Educação (ADEs) vêm se configurando como uma nova estratégia de implementação do regime de colaboração nas relações intergovernamentais. A proposta, formulada e apoiada pelo movimento empresarial Todos pela Educação (TPE), foi aprovada e normatizada pelo Conselho Nacional de Educação (CNE) por meio da Resolução n ${ }^{\circ}$ 1, de 30 de maio de 2012 (BRASIL, 2012c).

Considerando-se que a construção de um Sistema Nacional de Educação (SNE) passa por colocar em prática o Regime de Colaboração ${ }^{1}$, conforme previsto no Art. 211 da Constituição Federal, os ADEs envolvem novos modelos organizacionais e administrativos e têm como referência o associativismo territorial, a cooperação horizontal e o trabalho em rede entre municípios com proximidade geográfica e características sociais e econômicas semelhantes (BRASIL, 2011a).

O novo modelo de colaboração foi elaborado conforme a perspectiva gerencial da administração pública. Pautada na "[...] dispersão de poder para uma pluralidade de organizações de instituições e empresas" (NEWMAN; CLARKE, 2012, p. 371) e na adoção de "[...] novos aparelhos de responsabilização e avaliação" (NEWMAN; CLARKE, 2012, p. 353), a forma gerencial tem como foco a eficácia econômica dos gastos públicos e o desempenho (cumprimento de metas como indicador de qualidade).

Apresentado como instrumento de gestão pública para a melhoria da qualidade social da educação, o modelo configura-se como uma nova forma de coordenação e de cooperação entre os entes federados e, também, como uma modalidade de parceria público-privada, ou seja, de acordos formalmente firmados pelas esferas governamentais, particularmente os municípios, com institutos

\footnotetext{
${ }^{1}$ Conforme Araújo (2013, p. 788), o “[...] regime de colaboração é um instituto jurídico e político que regulamenta a gestão associada dos serviços públicos, sendo afeto às competências materiais comuns previstas no art. 23 da Constituição Federal de 1988. As competências materiais comuns podem ser definidas como aqueles serviços públicos que devem ser prestados por todos os entes federados, sem preponderância e de forma cumulativa, para garantir a equalização das condições de vida em todo o território de um Estado organizado em bases federativas. Neste sentido, o regime de colaboração é um dos mecanismos da matriz cooperativa ou intraestatal do federalismo".
}

Práxis Educativa, Ponta Grossa, v. 15, e2014343, p. 1-23, 2020 Disponível em: <http://www.revistas2.uepg.br/index.php/praxiseducativa> 
e fundações ligados a empresas privadas e a organizações diversas. De nossa perspectiva, tal parceria, mais do que um instrumento para soluções colaborativas na administração pública, configura-se como uma nova estratégia para que o setor privado influencie diretamente a gestão da Educação Básica pública e, ao mesmo tempo, expanda e controle o mercado educacional. Para procedermos à análise, focalizaremos as bases legais e institucionais dos ADEs como novo instrumento de gestão pública e também as implicações de sua implementação para a educação pública.

\section{Arranjos de Desenvolvimento da Educação (ADEs): Regime de Colaboração mediante parcerias público-privadas}

Em face do desafio de melhorar a qualidade social da educação em determinado território, em termos de acesso, permanência, aprendizagem e conclusão escolar, os $\mathrm{ADEs}^{2}$ são entendidos como uma ferramenta para o fortalecimento e o estímulo à cooperação e ao associativismo entre os entes federados, particularmente entre os municípios no que tange à organização de seus sistemas de ensino ${ }^{3}$ (BRASIL, 2011a).

A proposta, elaborada pelo movimento empresarial TPE (ARAÚJO, 2012) no processo de construção do SNE, é um instrumento de gestão pública e tem como objetivo a implementação do Regime de Colaboração (BRASIL, 2011a). Seu surgimento reporta-nos ao Plano de Desenvolvimento da Educação (PDE). Lançado em 2007, sua elaboração contou com forte influência e participação do movimento empresarial TPE. Conforme exposto no documento - o "Plano de Desenvolvimento da Educação: razões, princípios e programas" -, a finalidade de "[...] reduzir desigualdades sociais e regionais na Educação exige pensá-la no plano de país" e o "PDE pretende responder a esse desafio através de um acoplamento entre as dimensões educacional e territorial operado pelo conceito de arranjo educativo" (BRASIL, 2007a, p. 6).

A construção de ações colaborativas, especialmente nos ADEs, começou a ganhar forma no final de 2008, quando o Instituto Votorantim entrou em contato com o movimento TPE para encontrar maneiras de atuar coletivamente em 12 municípios do Recôncavo Baiano, diagnosticados com baixos índices educacionais. No mesmo período, o TPE vinha promovendo com o Ministério da Educação (MEC) e a iniciativa privada encontros para debater estratégias que evitassem a sobreposição de esforços e de recursos entre os níveis de governo (CARVALHO, 2018).

A partir de 2009, contando com o apoio do TPE e em parceria com diferentes instituições públicas e privadas, foram realizadas as primeiras experiências de ADEs. Incentivada pelo Instituto Votorantim, a primeira delas, ocorrida nos 12 municípios do Recôncavo Baiano, serviu de modelo e inspiração para outras regiões: no Agreste Meridional de Pernambuco, incentivado pelo Serviço Social da Indústria - Pernambuco (SESI-PE) com apoio da Confederação Nacional da Indústria $(\mathrm{CNI})$, a experiência envolveu 23 municípios; no Corredor Carajás do Maranhão, incentivada pela Fundação Vale e estruturada pela Comunidade Educativa (CEDAC), envolveu 16

\footnotetext{
2 A expressão “arranjos educacionais” é utilizada no plural por não existir um único modelo (BRASIL, 2011a).

${ }^{3}$ Considerando-se que a "Educação Básica é constituída, em grande medida, por uma duplicidade de redes convivendo em um mesmo território: escolas municipais e estaduais", entende-se que “[...] é preciso coordenar a atuação dos níveis de governo a fim de evitar sobreposições e garantir padrões de qualidade similar. Infelizmente, há pouquíssimo diálogo e colaboração entre as redes de ensino" (ABRUCIO, 2012, p. 20).
} 
Arranjos de Desenvolvimento da Educação (ADEs) como estratégia de atuação do setor privado...

municípios; no Noroeste de São Paulo, liderada pelo município de Votuporanga, envolveu 18 municípios $^{4}$ (BRASIL, 2011a).

Com base nessas experiências, consideradas exitosas, foi formulada a proposta de ADEs, cuja finalidade seria a implementação do regime de colaboração entre os entes federados, com ênfase na colaboração horizontal entre os municípios e na construção do Sistema Nacional de Educação. A proposta adquiriu fôlego diante da ausência de legislação complementar para a regulamentação do regime de colaboração entre União, estados, Distrito Federal e municípios, conforme preconizado no Art. 23, Parágrafo Único, da Constituição Federal de 1988 (BRASIL, 2018, p. 36). Consta em seu Art. 211, parágrafo $4^{\circ}$ : "Na organização de seus sistemas de ensino, a União, os Estados, o Distrito Federal e os Municípios definirão formas de colaboração, de modo a assegurar a universalização do ensino obrigatório (NR)" (BRASIL, 2018, p. 162).

Cury (2012, p. 32) lembra-nos de que a Constituição de 1988, diferentemente das anteriores, ao optar por um "regime normativo e político, plural e descentralizado", montou um sistema de repartição de competências e de atribuições legislativas entre os integrantes do sistema federativo, reconhecendo a autonomia destes, incluindo os municípios, e obedecendo ao princípio da colaboração recíproca. Por isso, para o autor, " [...] a cooperação exige entendimento mútuo entre os entes federativos, e a participação supõe a abertura de novas arenas políticas de deliberação e de tomada de decisão", ampliando "[...] o número de sujeitos políticos capazes de tomar decisões" (CURY, 2012, p. 32). Considera-se, portanto, que a regulamentação desse aspecto é "[...] matéria da mais alta importância e significado para o conjunto das ações públicas e, em especial, para a manutenção e desenvolvimento do ensino [...]" (CURY, 2012, p. 34).

Em acordo com a nova característica da federação brasileira, a Emenda Constitucional n ${ }^{\circ}$ 53, de 19 de dezembro de 2006, deu nova redação aos artigos 7, 23, 30, 206, 208, 211 e 212 da Constituição Federal de 1988 e ao artigo 60 do Ato das Disposições Constitucionais Transitórias. $\mathrm{Na}$ nova redação, consta no Art. 23: "Parágrafo único. Leis complementares fixarão normas para a cooperação entre a União e os Estados, o Distrito Federal e os Municípios, tendo em vista o equilíbrio do desenvolvimento e do bem-estar em âmbito nacional (NR)" (BRASIL, 2006, n.p.).

A Emenda Constitucional no $59^{5}$, de 11 de novembro de 2009, em seu Art. $4^{\circ}$, altera o caput do Art. 214 da Constituição Federal, em cuja redação é acrescido o inciso VI.

Art. 214. A lei estabelecerá o plano nacional de educação, de duração decenal, com o objetivo de articular o sistema nacional de educação em regime de colaboração e definir diretrizes, objetivos, metas e estratégias de implementação para assegurar a manutenção e desenvolvimento do ensino em seus diversos níveis, etapas e modalidades por meio de ações integradas dos poderes públicos das diferentes esferas federativas que conduzam a:

VI - estabelecimento de meta de aplicação de recursos públicos em educação como proporção do produto interno bruto (NR) (BRASIL, 2009, p. 2).

\footnotetext{
4 Atualmente, não se sabe ao certo, mas, em 2012, “[...] cerca de 200 municípios brasileiros estavam se organizando em espécies de redes educativas [ADEs], que contavam com a colaboração de empresas" (MANDELLI, 2012, p. 1).

${ }^{5} \mathrm{Na}$ referida Lei, foi acrescentado o parágrafo $3^{\circ}$ ao Art. 76 do Ato das Disposições Constitucionais Transitórias, no qual consta a decisão de reduzir, anualmente, a partir do exercício de 2009, o percentual da Desvinculação das Receitas da União incidente sobre os recursos destinados à manutenção e ao desenvolvimento do ensino, tema do Art. 212 da Constituição Federal. Além disso, foi dada nova redação aos incisos I e VII do Art. 208, de forma a prever a obrigatoriedade do ensino de quatro a dezessete anos e a ampliação da abrangência dos programas suplementares para todas as etapas da Educação Básica, ao parágrafo $4^{\circ}$ do Art. 211, ao parágrafo $3^{\circ}$ do Art. 212 e ao caput do Art. 214, no qual foi inserido o inciso VI.
}

Práxis Educativa, Ponta Grossa, v. 15, e2014343, p. 1-23, 2020 Disponível em: <http://www.revistas2.uepg.br/index.php/praxiseducativa> 
Nesses termos, observa-se que a Emenda Constitucional no 59 ,

[...] passou a exigir a construção de caminhos institucionais concretos para a regulamentação do Regime de Colaboração e a efetivação do Sistema Nacional de Educação (SNE), a ser estruturado por meio da construção e consolidação de novos patamares e formas de cooperação entre os entes federados, cuja base se articule a um projeto de Estado para a educação nacional (BRASIL, 2012a, p. 3).

Ressaltamos que esse foi um tema central da Conferência Nacional de Educação (CONAE) ocorrida em 2010, o qual apontou, inclusive, "[....] para a necessidade desta organicidade dando sentido e concretude ao próximo Plano Nacional de Educação, cuja instituição, agora, conquistou status constitucional" (BRASIL, 2012a, p. 3). Considerando a inexistência de um Sistema Nacional de Educação, a CONAE situou o Plano Nacional de Educação (PNE) como uma das formas de materialização da colaboração ou corresponsabilidade entre os sistemas de ensino, ou seja, de envolvimento de todas as esferas de governo (federal, estadual/distrital e municipal) no contexto da cooperação federativa.

Portanto, conforme argumenta Ramos (2012, p. 68), “[....] a construção de um SNE passa, necessariamente, por colocar em prática o Regime de Colaboração, incorporando mecanismos capazes de fortalecê-lo não só entre as três esferas de governo (União, estados e municípios), mas também entre municípios, tomando como referência a organização territorial do Estado". Segundo Abrucio (2012, p. 27), “[....] a área da Educação terá de criar um sistema nacional de política pública, o que envolverá a criação de instrumentos de coordenação federativa, entre os quais um mecanismo de cooperação intergovernamental. Foi essa a origem da proposta de Arranjo de Desenvolvimento da Educação (ADE)".

$\mathrm{Na}$ Resolução no 4 CNE/CEB, de 13 de julho de 2010, estão definidas as diretrizes curriculares nacionais gerais para a Educação Básica. Consta, em seu Art. $7^{\circ}$ :

A concepção de educação deve orientar a institucionalização do regime de colaboração entre União, Estados, Distrito Federal e Municípios, no contexto da estrutura federativa brasileira, em que convivem sistemas educacionais autônomos, para assegurar efetividade ao projeto da educação nacional, vencer a fragmentação das políticas públicas e superar a desarticulação institucional. (BRASIL, 2010, p. 824).

Enfim, a inexistência de normatização do Sistema Nacional de Educação e do Regime de Colaboração deu margem para que o empresariado regulamentasse os ADEs e obtivesse seu reconhecimento pelo MEC, tornando-os instrumento de gestão pública para a melhoria da qualidade social da educação.

O primeiro passo foi o encaminhamento da proposta ao CNE em 2010. Por meio da "Portaria CNE/CEB no 7/2010" (BRASIL, 2011a, p. 19), foi composta uma comissão ${ }^{6}$ com a finalidade de analisá-la. Segundo Argollo (2015), nesse documento, apontava-se:

[...] a importância de se aprofundar estudos sobre a possibilidade de constituição de consórcios públicos como forma de consolidação dos ADEs; demarca a possibilidade de uso dos recursos do FUNDEB para projetos e programas implementados de modo consorciado ou em forma de ADE; $e$ aponta a possibilidade de transferência de assistência técnica el ou financeira para os municípios

\footnotetext{
${ }^{6}$ A comissão foi composta pelos conselheiros César Callegari (presidente) e Mozart Neves Ramos (relator), ambos integrantes do Todos Pela Educação. Dela participaram também Adeum Hilário Sauer (ex-presidente da UNDIME), José Fernandes de Lima (Diretor de Programas da CAPES e Secretário de Educação de Sergipe no período de 20072010) e Rita Gomes do Nascimento (Membro do Colegiado de Culturas Indígenas do Conselho Nacional de Políticas Culturais (CNPC) do Ministério da Cultura (MinC) Membro da Comissão Nacional de Educação Escolar Indígena (CNEEI) (BRASIL, 2011a).
} 
Arranjos de Desenvolvimento da Educação (ADEs) como estratégia de atuação do setor privado...

consorciados, por parte do FNDE ou do MEC, como mecanismo de colaboração e compartilhamento de competências. (ARGOLO, 2015, p. 70, grifos da autora).

A proposta foi aprovada pelo CNE com base no Parecer no 9 (BRASIL, 2011a), que foi homologado pelo MEC e publicado no Diário Oficial da União em 22 de novembro de 2011. Na Resolução no 1 (BRASIL, 2012a) encontra-se a regulamentação da proposta e, em seu Art. $7^{\circ}$, conforme definido na Lei $\mathrm{n}^{\mathrm{o}} 11.107^{7}$, de 6 de abril de 2005, consta:

O ADE pode assumir o modelo de consórcio, constituído exclusivamente por entes federados como uma associação pública ou como entidade jurídica de direito privado sem fins lucrativos, podendo realizar acordos de cooperação e parceria com órgãos públicos e instituiçoes privadas e não governamentais. (BRASIL, 2012a, p. 3, grifo nosso).

Consideramos importante ressaltar que os consórcios públicos são voltados ao atendimento de interesses recíprocos ou de cooperação federativa por meio da gestão associada de serviços públicos. Assim, esse tipo de consórcio, conforme consta no Decreto n ${ }^{\circ}$ 6.017, de 17 de janeiro de 2007 , Art. $2^{\circ}, I^{8}$, é "[...] pessoa jurídica formada exclusivamente por entes da federação [...]" e constituída “[...] como associação pública, com personalidade jurídica de direito público e natureza autárquica, ou como pessoa jurídica de direito privado sem fins econômicos"” (BRASIL, 2007 b, p. 2). Os consórcios podem envolver a cooperação apenas de entes de uma esfera ou de mais esferas de governo (Municípios, Estados e Distrito Federal, e União) ${ }^{10}$.

Não por acaso, a proposição de constituição de consórcios públicos como forma de consolidação dos ADEs tem sido questionável (ABICALIL, 2013). Isso ocorre também com o regime de colaboração mediante ADEs, considerado de um "novo" tipo (ARGOLLO; MOTTA, 2015), especialmente porque abre a possibilidade de os municípios atuarem coletivamente, em parceria e colaboração com estados, Ministério da Educação e institutos e fundações ligados a empresas privadas.

Ao analisar o processo de normatização do ADEs, Araújo (2012) chama-nos atenção para o fato de que a proposta do empresariado ligado ao movimento Todos Pela Educação ganhou força no debate parlamentar. Desconsiderando a normativa jurídico-política, bem como os educadores que, na $\mathrm{CONAE}^{11}$, discutiam a elaboração do novo PNE, tal movimento tomou o que ela denomina de "atalho silencioso do empresariado". A autora argumenta que "[...] o regime de colaboração para a educação só pode ser regulamentado por Lei complementar, o que requer aprovação no Congresso Nacional por quórum qualificado” (ARAÚJO, 2012, p. 522-523).

\footnotetext{
${ }^{7}$ A Lei no 11.107, de 6 de abril de 2005, com a finalidade de disponibilizar um instrumento intergovernamental de cooperação entre os entes federativos, dispõe sobre normas gerais de contratação de consórcios públicos e dá outras providências (BRASIL, 2005).

8 O referido Decreto estabelece normas para a execução da Lei no 11.107, de 6 de abril de 2005.

${ }^{9}$ Conforme consta no Art. $6^{\circ}, \int 2^{\circ}$, da Lei no 11.107: “O consórcio público, com personalidade jurídica de direito público ou privado, observará as normas de direito público no que concerne à realização de licitação, à celebração de contratos, à prestação de contas e à admissão de pessoal, que será regido pela Consolidação das Leis do Trabalho (CLT), aprovada pelo Decreto-Lei n ${ }^{\circ}$ 5.452, de $1^{\circ}$ de maio de 1943. (Redação dada pela Lei $n^{\circ} 13.822$, de 3 maio de 2019)" (BRASIL, 2005, n.p.).

$10 \mathrm{O}$ âmbito de atuação do consórcio público corresponde à soma dos territórios dos municípios ou estados consorciados, facultada a participação da União como associada. Conforme Art. $1^{\circ} \int 2^{\circ}$, “[...] a União somente participará de consórcio público de que também faça parte o Estado ou todos os Estados em cujos territórios estejam situados os Municípios consorciados" (BRASIL, 2005, n.p.).

${ }^{11}$ A Conferência Nacional de Educação (CONAE) tomou como eixo de referência o tema "Construindo um Sistema Nacional Articulado de Educação: O Plano Nacional de Educação, diretrizes, estratégias de ação”.
}

Práxis Educativa, Ponta Grossa, v. 15, e2014343, p. 1-23, 2020 Disponível em: <http://www.revistas2.uepg.br/index.php/praxiseducativa> 
Em 28 de setembro de 2011, no intuito de promover a institucionalização de arranjos educativos e estimular sua implantação, foi apresentado, no âmbito do legislativo, o Projeto de Lei $\mathrm{n}^{\mathrm{o}}$ 2.417, de 2011 ${ }^{12}$ (BRASIL, 2011b), de autoria do Deputado Alex Canziani (PTB-PR), que reiterou a necessidade de colaboração envolvendo a atuação de instituições privadas:

Art. $3^{\circ}$ Um Arranjo de Desenvolvimento da Educação (ADE) promoverá a ação coordenada das instituições públicas responsáveis pela Educação nos Municípios articulados e de todas as outras instituições, públicas e particulares, neles sediadas com interesse manifesto em promover a melhoria da educação no território abrangido.

Parágrafo único. Um ADE deverá ter uma equipe gestora, coordenada por um agente local, oriundo dos quadros das instituições públicas ou privadas envolvidas, responsável pela mobilização dos entes participantes (BRASIL, 2011b, n.p., grifo nosso).

$\mathrm{Na}$ interpretação de Argollo (2015, p. 71), o referido projeto revela "[...] intenções subjacentes em torno da institucionalização ADEs, em 'reconfigurar' a concepção do sistema educacional público [...] em decorrência das parcerias público-privadas", particularmente nas redes municipais de educação.

Ressaltamos que, durante o processo de reestruturação do MEC, foi instituída a Secretaria de Articulação com os Sistemas de Ensino (SASE) ${ }^{13}$ pelo Decreto $n^{\circ} 7.480^{14}$, de 16 de maio de 2011 (BRASIL, 2011c). Dentre suas atribuições específicas, consta: "[...] estimular a ampliação do regime de cooperação entre os entes federados, apoiando o desenvolvimento de ações para a criação de um sistema nacional de educação" (BRASIL, 2011c, p. 20). As ações dessa secretaria estavam articuladas à agenda educacional "pactuada" com o movimento TPE (ARGOLLO, 2015), conforme fica explícito no Decreto n ${ }^{\circ}$ 6.094, de 24 de abril de 2007 (BRASIL, 2007c), que dispõe sobre a implementação do Plano de Metas Compromisso Todos pela Educação pela União Federal, em regime de colaboração com municípios, Distrito Federal e estados e de participação das famílias e da comunidade, mediante programas e ações de assistência técnica e financeira, visando a mobilização social pela melhoria da qualidade da Educação Básica.

Considerando o desafio de estimular e ampliar a cooperação entre os entes federados e coordenar a agenda instituinte do SNE, essa Secretaria desempenhou um papel relevante na

${ }^{12}$ A proposição encontra-se atualmente sujeita à apreciação do Plenário em regime de prioridade. Seu conteúdo está correlacionado a mais dois projetos de Lei - PL no 7.420, de 2006 e PL no 5.519, de 2013. Em 7 de outubro de 2011, o Projeto de Lei n ${ }^{\circ}$ 2.417, foi Apensado, para tramitação conjunta, ao Projeto de Lei n ${ }^{\circ}$ 7.420, de 2006, de autoria da deputada Raquel Teixeira (PSDB-GO), um texto que "Dispõe sobre a qualidade da educação básica e a responsabilidade dos gestores públicos na sua promoção”. Em 11 de junho de 2013, foi Apensado ao PL n 5.519, de 2013, de autoria do Deputado Paulo Rubem Santiago (PDT-PE), com a seguinte ementa: Institui o Sistema Nacional de Educação. Foi requerida a desapensação em 27 de junho de 2013, o que foi indeferido em 6 de agosto de 2013. Em 3 de março de 2016, foi requerida a desapensação do Projeto de Lei no 2.417, de 2011, do Projeto de Lei no 7.420, de 2006, e, por consequência, do conjunto de projetos sob a responsabilidade de análise dessa Comissão Especial. Em 15 de março de 2016, o requerimento foi indeferido por se tratar de matéria correlata. Em 3 de outubro de 2019, foi requerida à Mesa Diretora da Câmara dos Deputados a apensação do PL-2417 de 2011 ao PL-5.182/2019, que dispõe sobre Arranjos de Desenvolvimento da Educação (ADE). Em 22 de outubro de 2019, foi apresentado o Requerimento n. 2.758/2019, pela Deputada Luisa Canziani (PTB/PR), que "Requer a desapensação dos projetos de lei n" 2.417, de 2011, e no 5.182, de 2019, do projeto de lei no 7.420, de 2006" (BRASIL, 2019b, p. 1).

${ }^{13} \mathrm{Em} 1^{\circ}$ de dezembro de 2015, foi anunciada a extinção da Secretaria de Articulação com os Sistemas de Ensino (SASE), responsável, entre outras frentes, por apoiar a implementação do PNE nos estados e municípios.

${ }^{14}$ Esse Decreto foi revogado pelo Decreto no 7.690, de 2 março de 2012, que aprovou a Estrutura Regimental e o Quadro Demonstrativo dos Cargos em Comissão e das Funções Gratificadas do Ministério da Educação. Atualmente, encontra-se em vigência o Decreto $n^{\circ} 9.005$, de 14 de março de 2017, que aprovou a Estrutura Regimental e o Quadro Demonstrativo dos Cargos em Comissão e das Funções de Confiança do Ministério da Educação, remanejou cargos em comissão e substituiu cargos em comissão do Grupo-Direção e Assessoramento Superiores (DAS) por Funções Comissionadas do Poder Executivo - FCPE (BRASIL, 2017a).

Práxis Educativa, Ponta Grossa, v. 15, e2014343, p. 1-23, 2020 Disponível em: <http://www.revistas2.uepg.br/index.php/praxiseducativa $>$ 
Arranjos de Desenvolvimento da Educação (ADEs) como estratégia de atuação do setor privado...

institucionalização dos arranjos educacionais. No Relatório de Gestão do Exercício 2012 no Planejamento Estratégico da SASE 2012-2014 (BRASIL, 2012e, p. 19), estão previstas, dentre algumas ações, as de "[...] apoiar e fomentar ações de articulação entre os sistemas de ensino por meio de planos regionais de educação desenvolvendo e disseminando metodologia(s) de construção de arranjos territoriais de desenvolvimento da educação (ADE)". No Relatório de Gestão do Exercício de 2013, consta: "Compete à SASE propor o aperfeiçoamento dos instrumentos jurídicos de cooperação federativa, o que pode ser feito pela via do estímulo às ações de cooperação e colaboração em territórios formados por grupos de municípios" (BRASIL, 2014a, p. 22). Nos relatórios subsequentes (anos de 2015 e 2016), consta que foi dado prosseguimento ao aperfeiçoamento dos "[...] mecanismos e instrumentos de cooperação federativa, estimulando as formas de colaboração, desempenhando um papel mediador, indutor e facilitador da pactuação" (BRASIL, 2016b, p. 54).

O MEC, “[...] tendo em vista o debate sobre o aperfeiçoamento e/ou a indução de instrumentos jurídicos de cooperação federativa e sobre possíveis estímulos à colaboração entre os sistemas de ensino" (BRASIL, 2015a, p. 7) e em continuidade ao Parecer CNE/CEB no 9 (BRASIL, 2011a), criou, por meio da Portaria n $1.238^{15}$, de 11 de outubro de 2012 (BRASIL, 2012d), um grupo de trabalho com o fim de elaborar estudos sobre a implementação do regime de colaboração na forma de ADEs. Dentre outras atribuições, esse grupo deveria "[...] discutir conceitos, elencar experiências relevantes de organização territorial e formas de colaboração já implantadas ou em implantação, caracterizando-as, identificando êxitos e dificuldades" (BRASIL, 2012d, Art. 3, Inciso III, p. 1). Deveria também “[...] aprofundar estudos sobre a constituição de consórcios públicos como forma de consolidação dos arranjos, sobre vulnerabilidades educacionais com foco microrregional, sobre possibilidades de aporte de recursos e sobre o direcionamento de ações e programas de apoio" (BRASIL, 2012d, Art. 3, Inciso V, p. 1).

Os trabalhos foram concluídos em julho de 2015, quando o "Relatório Final do GT-ADE" foi divulgado pelo MEC. Nesse relatório, com a finalidade de buscar "instrumentos fortes e sustentáveis" de articulação federativa, deslocou-se "[...] a ideia de arranjo horizontal entre os municípios para ideia de território" (BRASIL, 2015a, p. 6), articulada ao conceito de "cooperação federativa". Nesse caso, englobam-se as múltiplas formas de colaboração além dos ADEs, dentre as quais os consórcios públicos.

Embora se reconheça a qualidade dos ADEs como uma espécie de "embrião de uma cultura de colaboração" (BRASIL, 2015a, p. 54), o documento destaca sua fragilidade e insuficiência como política pública. Em seus termos, os "[...] denominados 'Arranjos de Desenvolvimento da Educação' são frágeis do ponto de vista institucional, pois não são constituídos enquanto figuras jurídicas e em geral não alcançam níveis elevados de participação e acompanhamento social” (BRASIL, 2015a, p. 58). Além disso, de “[...] forma complementar, há pouca clareza ou simplesmente inexistem mecanismos de financiamento declarados e as relações com a sociedade também são aspectos que carecem de atenção: as iniciativas, em geral, não contam com mecanismos institucionalizados de transparência e de controle social" (BRASIL, 2015a, p. 54). Ao mesmo tempo, porém, o grupo de trabalho indica que: "O ADE pode e deve ser considerado e aproveitado no escopo de sua característica principal: como uma articulação informal que pode

\footnotetext{
15 A Portaria n ${ }^{\circ}$ 1, de 19 de fevereiro de 2013, publicada no Diário Oficial da União, de 20 de fevereiro de 2013, designa representantes dos órgãos e entidades que comporiam o Grupo de Trabalho para elaborar estudos sobre a implementação do regime de colaboração mediante Arranjos de Desenvolvimento da Educação, nos termos do Artigo $2^{\circ}$, \2, da Portaria n 1.238 , de 11 de outubro de 2012. A referida Portaria foi retificada no Diário Oficial da União, Seção 2, p. 39, de 20 de maio de 2013. A Portaria n ${ }^{\circ}$, de 8 de janeiro de 2015, altera o Art. $3^{\circ}$ da Portaria no 1.238 , de 11 de outubro de 2012, e define que o "GT-ADE apresentará o relatório final até 30 de abril de 2015" (BRASIL, 2015a).
}

Práxis Educativa, Ponta Grossa, v. 15, e2014343, p. 1-23, 2020 Disponível em: <http://www.revistas2.uepg.br/index.php/praxiseducativa> 
'evoluir' para um mecanismo de cooperação juridicamente forte e legitimado" (BRASIL, 2015a, p. 58, grifo do autor).

Outro aspecto a ser considerado é que o relatório corrobora o regime de colaboração horizontal característico dos ADEs, sem que, contudo, sejam questionadas as parcerias públicoprivadas com um de seus pilares (MOTTA; ARGOLLO, 2016). Mais do que isso, o documento contribui para que o fortalecimento da organização entre sistemas de ensino não se restrinja a instituições públicas, pois apresenta um "[...] leque de experiências muito expressivas, incluídas aquelas sob a denominação de arranjos de desenvolvimento da educação [...] que poderiam apontar contribuições para a área educacional" (BRASIL, 2015a, p. 7).

Na perspectiva da Brasil (2015a) em "Instituir um Sistema Nacional de Educação: agenda obrigatória para o país”, o Regime de Colaboração é

[...] um princípio, que deverá orientar as leis que instituem os sistemas de ensino nacional, estaduais (obrigatórios) e municipais (facultativos - LDB artigo 10). Para que o sistema nacional se efetive, as leis que o instituirão deverão determinar que os entes federativos, ao organizarem seus próprios sistemas de ensino, o façam por intermédio de leis vinculadas às leis do SNE, sempre prevendo as formas de colaboração necessárias para que os pactos federativos se concretizem na prática. Será por intermédio de formas características de colaboração, em cada Unidade Federativa (estados e DF), incluindo o papel da União, que se garantirá diversidade na unidade do sistema nacional.

Por essa razão entendemos que o regime de colaboração, em si, não precisa ser regulamentado. Ele é o princípio que deve estar presente na organização dos sistemas de ensino, ou seja, nas suas leis instituidoras. Será necessário um grande esforço nacional de organização sistêmica, que certamente exigirá apoio técnico do Ministério da Educação (BRASIL, 2015a, p. 12).

Trata-se de dar concretude ao regime de colaboração ${ }^{16}$, conforme previsto no Artigo 211 da Constituição Federal. Nas "[...] leis que instituem os sistemas, os entes federativos [federal, estaduais e municipais] deverão deixar claro como se relacionarão com os demais entes federativos [...]", de modo a garantir "[...] o cumprimento das responsabilidades definidas nas normas de cooperação e nas novas regras de financiamento, todas direcionadas pelos referenciais nacionais de qualidade expressos na LDB" (BRASIL, 2015a, p. 11). Ao MEC cabe desempenhar o papel de indutor da cooperação federativa, estimulando o debate nacional e apoiando o desenvolvimento de ações alinhadas às metas previstas no PNE.

A incorporação de ADEs pelo PNE (2014-2024) foi mais um passo decisivo para relacionálos ao regime de colaboração. Conforme previsto no Art. $7^{\circ}$ da Lei n ${ }^{\circ} 13.005$, de 25 de junho de 2014 (BRASIL, 2014b), que aprova o PNE, a “[...] União, os estados, o Distrito Federal e os municípios atuarão em regime de colaboração, visando ao alcance das metas e à implementação das estratégias objeto deste Plano" (BRASIL, 2014b, p. 1). Nos parágrafos que integram esse artigo,

\footnotetext{
16 Segundo o documento, o conceito da cooperação se diferencia constitucionalmente do conceito de colaboração: “Do ponto de vista semântico, poder-se-ia ponderar que os termos 'colaboração' e 'cooperação' possuem rigorosamente a mesma significação. Porém, do ponto de vista constitucional, há que distinguir o sentido. Tal distinção se dá, essencialmente, pelo lugar constitucional que ocupam. No artigo 23, referem-se exclusivamente à relação interfederativa, entre os entes federados, alcançando todas as estruturas do Poder Público em sentido restrito, requerendo a regulação das normas de cooperação. Nas disposições em que a colaboração se apresenta, expressamente, a relação se dá entre sistemas de educação, cujas instituições públicas são partes, os entes federados possuem competências prioritárias específicas, organizam suas redes próprias, e aos quais todas as instituições educacionais privadas (em sua multiplicidade de formas jurídicas admitidas em lei) estão vinculadas. Essa complexa relação entre sistemas de educação, por outro lado, gera formas distintas de relação institucional, ora por convênios, ora por adesão a programas, ora por pactos ou acordos, ora por determinação legal. As variadas formas são atinentes à enorme diversidade de situações a serem resolvidas em regime de colaboração” (BRASIL, 2015c, p. 10-11).
}

Práxis Educativa, Ponta Grossa, v. 15, e2014343, p. 1-23, 2020 Disponível em: <http://www.revistas2.uepg.br/index.php/praxiseducativa $>$ 
são encontradas medidas que deveriam ser tomadas pelos entes federados para efetivar o regime de colaboração. No parágrafo $7^{\circ}$, consta: "O fortalecimento do regime de colaboração entre os Municípios dar-se-á, inclusive, mediante a adoção de arranjos de desenvolvimento da educação" (BRASIL, 2014b, p. 2). Maia (2017), em um estudo técnico sobre o regime de colaboração no PNE, observa que a premissa do Regime de Colaboração se faz presente no PNE quando

\begin{abstract}
[...] define prazo de um ano para que estados e municípios elaborem ou readéquem seus correspondentes planos de educação em consonância com as diretrizes, metas e estratégias previstas no Plano Nacional (art. $8^{\circ}$ ). O mesmo vale para os planos plurianuais, as diretrizes orçamentárias e os orçamentos anuais (art. 10), de modo a "viabilizar sua plena execução". Finalmente, o art. 13 define prazo de dois anos da publicação da lei para que se institua em lei específica o Sistema Nacional de Educação, "responsável pela articulação entre os sistemas de ensino, em regime de colaboração, para efetivação das diretrizes, metas e estratégias do Plano Nacional de Educação". (MAIA, 2017, p. 309).
\end{abstract}

O autor mostra a relevância dada ao regime de colaboração nos artigos da lei e nas estratégias estabelecidas para a consecução de cada uma das metas. Segundo ele, o princípio da colaboração perpassa todo o documento, sendo explicitado em "[...] 27 estratégias presentes em 11 das vinte metas $[1,2,3,6,7,15,16,17,18,19$ e 20] do plano" (MAIA, 2017, p. 310). Perpassa, assim, "[...] a oferta de todos os níveis e modalidade da educação básica, o tempo integral, a formação inicial e continuada e a valorização profissional dos professores, a gestão democrática e o compromisso de gasto público como percentual do PIB” (MAIA, 2017, p. 310).

Após a aprovação do PNE, iniciou-se o processo de estabelecimento de normas de cooperação federativa entre a União e os estados, o Distrito Federal e os municípios e entre os estados e os municípios para garantir o acesso à Educação Básica e à Educação Superior públicas, conforme a Lei de Diretrizes e Bases da Educação Nacional (BRASIL, 2019a). Em 22 de julho de 2014, foi apresentado pelo deputado Ságuas de Moraes (PT-MT) o Projeto de Lei Complementar (PLP) n $n^{\circ}$ 413, de 2014 (BRASIL, 2014c), cujo objetivo seria "[...] responder especificamente às disposições do artigo 23 da Constituição Federal, acelerada, agora, pela recente sanção da Lei n $^{\circ}$ 13.005 que estabelece o Plano Nacional de Educação e dá outras providências" (BRASIL, 2014c, p. 1). No Art. $5^{\circ}$, \ VII, do referido Projeto de Lei, consta que: "O Sistema Nacional de Educação objetiva garantir a universalização da educação e seu padrão de qualidade no território nacional", observando, dentre outros aspectos, a "[...] colaboração com as instituições educacionais e outras agências públicas e privadas” (BRASIL, 2014c, p. 2).

Cabe observar que a regulamentação da colaboração tem sido campo de disputa entre diferentes concepções, bem como entre os que consideram e os que não consideram a necessidade da regulamentação da colaboração entre os entes federados por lei complementar.

Motta e Argollo (2016), ao analisarem as proposições de institucionalização do SNE brasileiro, apontam para a consonância entre os elementos centrais do substitutivo ao PL $\mathrm{n}^{\circ} 413$, de 2014 (BRASIL, 2014c) e o Relatório final do Grupo de Trabalho - GT/ADE (2015). Segundo as autoras, a "[...] perspectiva 'territorial' [ou horizontal] do regime de colaboração, com a indicação de aberturas para a regulamentação das parcerias com o empresariado" (MOTTA; ARGOLLO, 2016, p. 289), fortalece seu protagonismo na definição e na implementação das políticas públicas para a educação brasileira.

Em 23 de novembro de 2017, o deputado Giuseppe Vecci (PSD) apresentou o Projeto de Lei Complementar (PLP) n 448, de 2017 (BRASIL, 2017b), com a seguinte ementa: "Regulamenta a cooperação federativa na área da educação". Em 22 de dezembro de 2017, o relator, deputado Glauber Braga (PSOL-RJ), da Comissão de Educação da Câmara dos Deputados, emitiu parecer favorável à aprovação do PLP no 413 e do PLP no 448 (BRASIL, 2017c). Em 2018, o PLP n 413 
foi retirado de pauta em diversas seções da referida comissão. Em 19 de dezembro de 2018, o deputado Glauber Braga (PSOL-RJ) apresentou o requerimento de apensação do Projeto de Lei Complementar no 413 ao Projeto de Lei Complementar no 15, de 2011 (BRASIL, 2011d), destinado ao estabelecimento de normas para a cooperação entre a União e os estados, o Distrito Federal e os municípios em termos de responsabilidade na gestão pública da educação escolar brasileira. Ambos os projetos tramitavam em regime de prioridade, mas, em 31 de janeiro de 2019, foram arquivados pela Mesa Diretora da Câmara dos Deputados nos termos do Artigo 105 do Regimento Interno da referida câmara.

Destacamos, assim, que o regime de colaboração se tornou central nos encaminhamentos da política educacional da atualidade e que os ADEs se configuraram como uma estratégia de cooperação seja para a extensão da cobertura e para a melhoria da qualidade da educação ou para o avanço do processo de privatização do público. A regulamentação do tema tem constituído um campo de disputas, com consequências profundas para a educação pública brasileira, conforme abordaremos a seguir.

\section{Implicações do novo modelo de colaboração para a educação pública}

Nestas reflexões, analisamos a hipótese de que os ADEs, se inseridos no contexto da reforma do Estado brasileiro e de redefinição das relações entre público e privado, a partir dos anos de 1990 até os dias atuais, mais do que um instrumento de soluções colaborativas, configuram uma nova estratégia para a incorporação de agentes privados como "parceiros" na formulação e na execução das políticas para a Educação Básica pública e, ao mesmo tempo, para a expansão e o controle do mercado educacional (CARVALHO, 2018, 2019).

A presença cada vez mais visível do setor privado (empresarial-financeiro), com ou sem fins de lucro, nas instâncias de formulação política, bem como suas diferentes formas de atuação, a exemplo da Grupo COC/Pearson, Editora Moderna/Santillana, Abril Educação/Tarpon, Grupo Objetivo, Grupo Positivo, Instituto Ayrton Senna, Fundação Lemann, dentre outros, envolvendo a venda de formação continuada, consultoria, treinamento, serviços técnicos, produtos, soluções para a "melhoria" da qualidade e dos serviços de gestão das escolas e das redes de ensino públicas, bem como a adoção de sistemas privados de ensino por parte das redes públicas de ensino, têm sido destacadas em diversos estudos (PERONI, 2015, 2018a, 2018b; ADRIÃO; PERONI, 2011; ADRIÃO; PERONI, 2013; ADRIÃO et al., 2016; ADRIÃO, 2017, 2018a, 2018b, ADRIÃO; DOMICIANO, 2018).

Ao abordar a tendência de mercantilização e de privatização da Educação Básica pública, as pesquisas evidenciam que são diferentes as estratégias para transformá-la em um campo para os negócios privados. Mecanismos diretos e indiretos têm sido empregados para submeter a educação pública ao processo de acumulação ampliada e de reprodução do capital (RIKOWSKI, 2017). Assim, os ADEs fazem parte desse processo de construção de normativas para a consolidação de novas formas de cooperação entre os entes federados envolvendo instituições privadas e não governamentais.

A crescente atuação dos empresários na formulação e na execução das políticas públicas está associada às disputas pela apropriação do fundo público por parte das empresas, que tentam "converter a receita do Estado em lucro privado" (RIKOWSKI, 2018, p. 280), e à evidente amplitude do gasto da União com instituições privadas com ou aparentemente sem fins de lucro. Nessas circunstâncias, ocorre "[...] a operacionalização e não a posse de instalações educacionais na transformação da função e da qualidade do dinheiro" (RIKOWSKI, 2018, p. 281): a propriedade permanece pública, mas são as instituições privadas com ou sem fins de lucro que assumem a 
Arranjos de Desenvolvimento da Educação (ADEs) como estratégia de atuação do setor privado...

direção dos processos pedagógicos, da formação de professores e de gestores, da avaliação, do monitoramento e da gestão dos sistemas de ensino público (PERONI, 2018a). Portanto, os interesses privados têm influenciado ou definido o conteúdo da política e a gestão da educação segundo seus propósitos, sendo profundas as consequências para a consolidação dos direitos sociais e da esfera pública no Brasil.

Nesse sentido, um movimento complexo de mercantilização e de privatização tem contribuído " [...] para mudar as redefinições históricas de educação pública e de escola estatal, bem como o papel do Estado, o que tem conduzido, por vezes, ao esvaziamento das escolas enquanto espaços públicos de decisão" (LIMA, 2018, p. 130). Uma forma específica de privatização, denominada por Lima (2018, p. 139) de "privatização lato senso", transcende a "indução da privatização" e a importação de processos de organização e gestão do setor privado para o setor público, envolvendo processos multiformes de "[...] 'privatização oculta', encoberta ou dissimulada na educação [...]", revela-se como “[...] um instrumento privilegiado de política pública [...]" (LIMA, 2018, p. 130).

Vivenciamos a instituição de um regime fiscal de contenção de gastos com despesas primárias e de cortes no custeio de despesas com manutenção e desenvolvimento da educação pública. Dentre as políticas mais recentes, podemos citar a aprovação da Emenda Constitucional $\mathrm{n}^{\circ}$ 95, de 15 de dezembro de 2016 (BRASIL, 2016a), que, ao estabelecer o congelamento dos gastos públicos durante vinte anos, nas chamadas despesas primárias do governo, permitindo apenas a reposição das perdas inflacionárias, por um lado, restringe investimentos na garantia dos direitos sociais, comprometendo o cumprimento das metas do PNE; por outro, parece indicar um cenário ainda mais favorável ao aprofundamento das parcerias público-privadas e dos processos de mercantilização e de privatização da Educação Básica pública brasileira.

Dados relativos à matrícula total na Educação Básica regular, disponíveis nas Sinopses Estatísticas do Censo Escolar ${ }^{17}$ (INEP, 2018), demonstram que, em 2017, 47,5\% das matrículas da Educação Básica estão sob a responsabilidade dos municípios, ente da federação que demonstra maior fragilidade financeira e administrativa, e que, desde 2001, como os demais entes federados, tem sua atuação restringida pela Lei de Responsabilidade Fiscal, Lei Complementar $n^{\circ} 101$, de 4 de maio de 2000 (BRASIL, 2000), a qual fixa os gastos governamentais com pessoal em no máximo 60\%. Na interpretação de Adrião e Domiciano (2018, p. 5), “[...] esses condicionantes explicam, em parte, a generalização de programas e políticas que se apoiam no setor privado, lucrativo ou não lucrativo, como ‘solução' para a oferta e gestão educacional em âmbito subnacional’.

Lembremos que as mudanças em curso desde os anos de 1990 inserem-se no movimento mais amplo de mundialização do capital e de redefinição do papel do Estado e de suas formas de atuação. Adotam-se, nesse processo, os princípios do modelo denominado gerencial, que envolve novas relações entre o público e o privado na oferta dos serviços sociais, particularmente os da educação pública.

À medida que o Estado se despe de atividades que tradicionalmente estiveram associadas ao setor público e ao interesse público, torna-se ascendente a presença de agentes privados na esfera estatal (CARVALHO, 2017). Essa tendência marca a transferência da autoridade ou da tomada de decisões do público para o domínio privado e "[...] deixa as responsabilidades ficarem cada vez mais diluídas quanto aos direitos materializados em políticas sociais” (PERONI, 2018b,

\footnotetext{
17 “O Censo Escolar da Educação Básica é uma pesquisa realizada anualmente pelo Instituto Nacional de Estudos e Pesquisas Educacionais Anísio Teixeira (Inep) em articulação com as Secretarias Estaduais e Municipais de Educação, sendo obrigatória aos estabelecimentos públicos e privados de educação básica, conforme determina o art. $4^{\circ}$ do Decreto n $6.425 / 2008$ " (INEP, 2018, p. 2).
}

Práxis Educativa, Ponta Grossa, v. 15, e2014343, p. 1-23, 2020 Disponível em: <http://www.revistas2.uepg.br/index.php/praxiseducativa> 
p. 102), além de criar mecanismos e instrumentos para estimular a atuação do setor privado na gestão da educação pública.

As mudanças têm contado com o forte apoio de organizações internacionais. Relatório recente do Banco Mundial, intitulado Um Ajuste Justo: Análise da eficiência e equidade do gasto público no Brasil. Brasil Revisão das despesas Públicas (BANCO MUNDIAL, 2017), contém recomendações aos estados e municípios brasileiros sobre o que as reformas do setor de educação devem levar em conta para aumentar a eficiência e a equidade e reduzir o custo fiscal. $\mathrm{Na}$ perspectiva do Banco, a "[...] contratação de empresas privadas para o fornecimento de serviços de educação também poderia melhorar o desempenho e a eficiência dos gastos públicos com educação [...]", sendo “[...] possível economizar quase 1\% do PIB” (BANCO MUNDIAL, 2017, p. 136-137).

No caso específico, é evidente a interferência dos ADEs nas relações entre os entes federativos. O novo modelo de cooperação, ao abrir canais para a atuação transversal de institutos e fundações privadas e não governamentais junto aos entes federados, afirma a corresponsabilidade dos empresários locais no desenvolvimento da educação pública, aspecto que coloca em suspeição o papel do Estado para assegurar sua manutenção e expansão, bem como a sua capacidade de gestão.

Embora o setor privado tenha sido utilizado "[...] para planejar, gerenciar e ou fornecer partes da educação pública” (PERONI, 2018a, p. 216), as novas relações entre o público e o privado têm sido aceitas e naturalizadas socialmente porque a propriedade permanece pública e o Estado continua sendo responsável pelo acesso, o que implica que os serviços continuam sendo "públicos". A atuação do setor privado parece menos sujeita a oposições quando a parceria envolve institutos e fundações, os quais, em geral, apresentam-se como braços de investimento social de corporações (ADRIÃO, 2017).

As instituições que, aparentemente, não têm fins de lucro ou não são dependentes de recursos públicos, evidentemente atuam em uma perspectiva de alinhamento entre filantropia e negócios orientada para novos empreendimentos, denominado "filantropia de risco" ou "filantropia 3.0" (BALL, 2014) ou, ainda, "filantrocapitalismo" (BISHOP; GREEN, 2008). Adrião e Domiciano (2018, p. 6) afirmam que se trata de "[...] fundações ou organizações similares a estas, vinculadas ao setor empresarial, que oferecem seus préstimos a governos, como parte de suas estratégias para ampliação e desenvolvimento de novos produtos e serviços os quais, por sua vez, alavancarão empresas emergentes". São, desse modo, "[...] ações que impactam a própria organização e o setor no qual investem, com vistas à remuneração do grupo privado" (ADRIÃO; 2018b, p. 79).

Concordamos com Argollo (2015) quando afirma que o conceito de ADEs, como instrumento de colaboração entre os munícipios, ao combinar educação, territorialidade e filantropia, cumpre a função de "[...] conformar a educação pública aos interesses políticoeconômicos do capital nos territórios diretamente relacionados a um grupo empresarial local" (ARGOLLO, 2015, p. 72). Suas possíveis implicações seriam o desmonte da estrutura vigente, a implementação de "novas instâncias de poder" e o "[...] retrocesso à luta pela educação pública como direito social e formação humana [...]", além do "[...] aprofundamento das desigualdades dos sistemas de ensino" (MOTTA; ARGOLLO, 2016, p. 295).

Os ADEs, ao envolverem a conformação de um novo modelo de gestão pública e uma nova relação colaborativa entre os entes federados e ao terem como referência a organização territorial, a atuação em rede e a participação de instituições privadas e não-governamentais, abrem novas oportunidades para os negócios privados, mesmo que indireta ou não abertamente nomeadas (CARVALHO, 2019). Nesses termos, cabe lembrarmos Rikowski $(2017,2018)$ quando analisa a 
Arranjos de Desenvolvimento da Educação (ADEs) como estratégia de atuação do setor privado...

expansão do capital para campos relativamente novos, como é o caso da educação estatal. Segundo ele, esse processo envolve um "devir", ou seja, o que Marx denominou de "tornar-se capital". Entretanto, "este 'movimento real' é uma possibilidade" que, segundo Marx, "[...] ainda-não está em ser, mas tornar-se" (RIKOWSKI, 2018, p. 279), o que pressupõe resistências e alternativas envolvendo a luta pelos interesses públicos e coletivos.

De nossa perspectiva, é preciso considerarmos a relação contraditória entre o público e o privado nas relações sociais capitalistas, bem como a natureza institucional do Estado moderno. Com base nas análises de Sguissardi (2015) e Peroni (2015, 2018a), entendemos que o estatal não é um polo oposto ao privado, mas um campo de disputas ou de correlação de forças entre classes sociais e projetos societários distintos. No contexto atual, esse campo tem sido homogeneizado por interesses privado-mercantis. Assim, o Estado, por meio de novas regulamentações jurídicoinstitucionais, tem atuado na criação de condições favoráveis à abertura de novos espaços de acumulação do capital que, até então, eram considerados fora do alcance da lucratividade, tornando mais evidente a relação entre capital e Estado, tanto institucional quanto pessoal (CARVALHO, 2018).

Nosso argumento é que vivenciamos o contexto da restruturação produtiva com base em um modelo flexível e da "mundialização do capital", com predominância de instituições financeiras, bem como dos "mercados financeiros" (CHESNAIS, 1996). Nesse contexto, o estilo de acumulação decorre da extrema centralização e da concentração de capital, da fusão entre corporações produtivas e financeiras sob novas formas, da hipertrofia da esfera financeira frente aos capitais produtivos e do aprofundamento do "[...] domínio das finanças sobre todas as outras áreas da economia, assim como sobre o aparato do Estado” (HARVEY, 2011, p. 41).

Em correspondência, o Estado assumiu um novo papel e uma nova forma de atuação, e essa reconfiguração recolocou em discussão a relação entre o público e o privado. A redefinição das fronteiras e a maior integração entre ambos leva ao crescente protagonismo de empresários e de grandes corporações empresariais na formulação e na execução da política para a Educação Básica pública.

A ausência de legislação complementar para o regime de colaboração entre União e estados e Distrito Federal e municípios, conforme preconizava a Constituição de 1988, abriu espaço para que o empresariado propusesse o modelo de ADEs. Estes são entendidos como um novo instrumento indutor da cooperação horizontal entre entes federados e da colaboração das instituições e das organizações educacionais que atuam em área territorial comum, já que o Sistema Nacional de Educação é conformado, em sua essência, pela perspectiva empresarial da gestão dos sistemas de ensino. Segundo Lima (2018, p. 132), o resultado são "[...] miscigenações complexas e hibridismos jurídicos e organizacionais que ainda há pouco tempo seriam considerados inéditos".

A materialização desse modelo implica nova oportunidade de negócios para as organizações do setor empresarial (CARVALHO, 2019). Ao redesenhar os mecanismos de gestão das redes municipais públicas de ensino e implementar novas instâncias de decisão e de gestão, extrapola-se a dimensão pública do Estado e incorpora-se a gestão empresarial nas redes públicas de ensino. Na concepção do CNE,

[...] ações colaborativas, no formato de arranjos de desenvolvimento da educação, devam ser instituídas e deva ser incentivada a sua implementação como um dos instrumentos da gestão pública da educação, que fortalece o regime de colaboração entre os entes federados e entre estes e a sociedade civil, com potencial de contribuir eficazmente para assegurar o direito a educação de qualidade social em determinado território. (BRASIL, 2011a, p. 17).

Práxis Educativa, Ponta Grossa, v. 15, e2014343, p. 1-23, 2020 Disponível em: <http://www.revistas2.uepg.br/index.php/praxiseducativa> 
Enfim, problematizando o processo de regulamentação do regime de colaboração em um contexto de expansão ampliada do capital, em que ocorre o novo formato de colaboração entre entes federados, assentado na instituição de parcerias público-privadas, mediante ADEs, “[...] objetiva reconfigurar o sentido social do espaço público do Estado e, com isso, também dos princípios e finalidades da educação pública" (ARGOLLO, 2015, p. 155). Nesse processo, marcado por disputas e correlação de forças, cabe reafirmar a "[...] coletivização das decisões na definição de políticas [...]" e a "[...] responsabilidade do Estado no processo de execução como o responsável pelas políticas universais" (PERONI, 2018a, p. 234), o que fortaleceria a dimensão pública do Estado e da educação.

\section{Considerações finais}

O objetivo, neste artigo, foi analisar os novos contornos que as ações e as proposições voltadas ao regime de colaboração vêm assumindo, dentre as quais os ADEs. Os novos formatos na relação entre o público e o privado dão abertura para a gestão pública compartilhada entre os entes federativos e instituições privadas e não-governamentais, visando a garantia do direito à educação e a melhor prestação desse serviço.

Alguns estudos (ABICALIL, 2013; ARAÚJO, 2013; OLIVEIRA; GANZELI, 2013; ARGOLLO; MOTTA, 2015) têm dado destaque para as novas relações intergovernamentais voltadas ao desenvolvimento da educação, mostrando a participação das unidades subnacionais e do governo central, a criação de novas estratégias nas disputas do fundo público, as novas formas de regramento do regime de colaboração, da constituição de fundos e do estabelecimento de parcerias, convênios, contratos, consórcios e arranjos diversos.

Almejando a melhoria da qualidade social da educação, o Parecer $n^{\circ} 9$ do CNE/CEB (BRASIL, 2011a) ressalta que as ações colaborativas, mediante ADEs, devem ocorrer "[...] sem que haja para isso transferência de recursos públicos para tais instituições [não-governamentais] e organismos privados" (BRASIL, 2011a, p. 18). No entanto, concordamos com Araújo (2012, p. 519) quando aponta a necessidade de se "[...] indagar quais seriam os interesses e as contrapartidas das mesmas para se engajarem nos arranjos, contribuindo para o avanço da teorização sobre as relações entre o público e o privado ou sobre a teorização relacionada ao quase-mercado nas políticas educacionais".

Observamos o reconhecimento de que é necessária a repactuação do federalismo brasileiro e de que é importante a existência de um Regime de Colaboração a fim de delimitar com "[...] propriedade e clareza os limites e responsabilidades de cada ente federado" (BRASIL, 2011a, p. 2) e, assim, evitar descontinuidades das políticas educacionais. Todavia, é preciso considerar que o modelo de ADEs, ao propor um novo formato colaborativo entre os entes federados, envolvendo especialmente o associativismo territorial, a colaboração horizontal e a possibilidade de participação de instituições privadas e não governamentais na gestão das redes municipais de ensino agrupados em determinado território, ou seja, envolvendo mais de uma rede pública, abre espaço para a atuação desses novos sujeitos nas relações dos municípios entre si e dos municípios com os estados e União. Ao mesmo tempo, desloca e implementa novos espaços de decisão política: os novos sujeitos passam a atuar diretamente, mediante convênios e termos de cooperação, na definição, no planejamento e na coordenação das ações no âmbito dos territórios associados, fragilizando a configuração de formas de colaboração que envolvam o compartilhamento das competências comuns entre diversos entes federativos (União, estados e municípios) e fortalecendo o papel estratégico das instituições privadas com ou sem fins de lucro e da sua lógica de gestão (indicadores, metas, resultados e responsabilização) no âmbito da gestão da Educação Básica pública. 
Arranjos de Desenvolvimento da Educação (ADEs) como estratégia de atuação do setor privado...

Cabe ressaltarmos que a proposição do regime de colaboração mediante ADEs tem como justificativa a promoção da qualidade social da educação em determinado território e a construção do Sistema Nacional de Educação. Por esse caminho, podem se institucionalizar como uma política de Estado e se constituir como um novo instrumento de gestão pública (BRASIL, 2011a, 2012a), de forma que o setor privado com ou sem fins de lucro poderá promover, estimular e liderar as relações de cooperação intermunicipal.

O novo modelo cooperativo, portanto, ao enfatizar a colaboração horizontal basicamente entre os municípios e a promoção da "[...] cultura do planejamento integrado e colaborativo na visão territorial e geopolítica" (BRASIL, 2011a, p. 2), sugere novas relações intergovernamentais entre as unidades subnacionais na gestão associada da educação, reforçando o "protagonismo local" e o "associativismo voluntário intermunicipal" (ARAÚJO, 2013, p. 789). Converge também para o envolvimento crescente do empresariado na reorganização dos processos de gestão, na redefinição dos fins e do conteúdo da política educacional e na disputa do fundo público, o que tem implicações para as relações federativas na consecução do direito à educação.

Considerando o cenário de indefinições e disputas em torno da normatização do regime de colaboração, reiteramos a importância da "[...] recomposição do pacto federativo de modo que a educação efetivamente seja uma responsabilidade compartilhada de todos os entes federados" (ARAÚJO, 2012, p. 526). Reiteramos, sobretudo, que as formas de colaboração e de gestão das redes de ensino devem ocorrer no âmbito da esfera pública.

\section{Referências}

ABICALIL, C. A. Sistema nacional de educação: os arranjos na cooperação, parceria e cobiça sobre o fundo público na educação básica. Educação \& Sociedade, Campinas, v. 34, n. 124, p. 803828, jul./set. 2013. DOI: http://dx.doi.org/10.1590/S0101-73302013000300009

ABRUCIO, F. L. Associativismo territorial para a coordenação intergovernamental. In: ABRÚCIO, F. L.; RAMOS, M. N. (Orgs.). Regime de colaboração e associativismo territorial: arranjos de desenvolvimento da Educação. São Paulo: Moderna, 2012. p. 17-30

ADRIÃO, T. A privatização da educação básica no Brasil: considerações sobre a incidência de corporações na gestão da educação pública. In: ARAÚJO, L.; MARCELINO, J. (Orgs.). Público x privado em tempos de golpe. São Paulo: Fundação Lauro Campos, 2017, p. 16-37.

ADRIÃO, T. Dimensões e formas da privatização da educação no Brasil: caracterização a partir de mapeamento de produções nacionais e internacionais. Currículo sem Fronteiras, v. 18, n. 1, p. 8 28, jan./abr. 2018a.

ADRIÃO, T. Sobre a incidência do setor privado nas redes estaduais de ensino no brasil: até onde os dados chegaram e o que se toma por fazer. In: GARCIA, T.; ADRIÃO, T. (Orgs.). Currículo, gestão e oferta da educação básica brasileira: incidências de atores privados nos sistemas estaduais (2005-2015). Curitiba: CRV, 2018b. p. 73-84.

ADRIÃO, T. et al. Grupos empresariais na educação básica pública brasileira: limites à efetivação do direito à educação. Educação \& Sociedade, Campinas, v. 37, n. 134, p. 113-131, jan./mar. 2016. DOI: http://dx.doi.org/10.1590/ES0101-73302016157605 
ADRIÃO, T.; PERONI, V. M. V. Consequências da atuação do Instituto Ayrton Senna para a gestão da educação pública: observações sobre dez casos em estudo. Práxis Educativa, Ponta Grossa, v. 6, n. 1, p.45-53, jan./jul. 2011. DOI: https://doi.org/10.5212/PraxEduc.v.6i1.0004

ADRIÃO, T.; PERONI, V. M. V. (Orgs.) Gestão Municipal da Educação e as parcerias com o Instituto Ayrton Senna. Goiânia: Funape; Recife: Anpae, 2013.

ADRIÃO, T.; DOMICIANO, C. A. A Educação Pública e as Corporações: avanços e contradições em uma década de ampliação de investimento no Brasil. FINEDUCA - Revista de Financiamento da Educação, Porto Alegre, v. 8, n. 3, p. 1-18, 2018. DOI: https://doi.org/10.17648/fineduca$\underline{2236-5907-v 8-79084}$

ARAÚJO, G. C. Federalismo cooperativo e arranjos de desenvolvimento da educação: o atalho silencioso do empresariado para a definição e regulamentação do regime de cooperação. Revista Brasileira de Política e Administração da Educação, Goiânia, v. 28, n. 2, p. 515-553, maio/ago. 2012. DOI: https://doi.org/10.21573/vol28n22012.37419

ARAÚJO, G. C. Federalismo e políticas educacionais no Brasil: equalização e atuação do empresariado como projetos em disputa para a regulamentação do regime de colaboração. Educação \& Sociedade, Campinas, v. 34, n. 124, p. 787-802, jul./set. 2013. DOI: http://dx.doi.org/10.1590/S0101-73302013000300008

ARGOLLO, J. Arranjos de desenvolvimento da educação: regime de colaboração de 'novo' tipo e mecanismo de reformulação do Sistema Nacional de Educação sob a direção do empresariado brasileiro. 2015. 174 f. Dissertação (Mestrado em Educação) - Universidade Federal do Rio de Janeiro, Rio de Janeiro, 2015.

ARGOLLO, J.; MOTTA, V. Arranjos de desenvolvimento da educação: regime de colaboração de 'novo' tipo como estratégia do capital para ressignificar a educação pública como direito. Universidade e Sociedade, Brasília, v. 56, p. 44-57, 2015.

BALL, S. Educação global S.A: novas redes políticas e o imaginário neoliberal. Tradução Janete Bridon. Ponta Grossa: Editora UEPG, 2014.

BANCO MUNDIAL. Um Ajuste Justo: Análise da eficiência e equidade do gasto público no Brasil. Brasil Revisão das despesas Públicas. 2017. Disponível em: <http://documents.worldbank.org/curated/en/884871511196609355/pdf/121480-REVISEDPORTUGUESE-Brazil-Public-Expenditure-Review-Overview-Portuguese-Final-revised.pdf>. Acesso em: 19 out. 2018.

BISHOP, M.; GREEN, M. How the rich can save the world. Londres: Bloomsbury Press, 2008.

BRASIL. [Constituição (1988)]. Constituição da República Federativa do Brasil. Brasília, DF: Senado, 1988.

BRASIL. Lei Complementar $\mathbf{n}^{\circ}$ 101, de 4 de maio de 2000. Estabelece normas de finanças públicas voltadas para a responsabilidade na gestão fiscal e dá outras providências. Brasília: Presidência da República, Casa Civil, Subchefia para Assuntos Jurídicos, [2000]. Disponível em: <http://www.planalto.gov.br/ccivil_03/leis/lcp/lcp101.htm>. Acesso em: 12 jun. 2019. 
BRASIL. Lei $\mathbf{n}^{\mathbf{0}} \mathbf{1 1 . 1 0 7}$, de 06 de abril de 2005. Dispõe sobre normas gerais de contratação de consórcios públicos e dá outras providências, 2005. Brasília: Presidência da República, Casa Civil, Subchefia para Assuntos Jurídicos, [2005]. Disponível em: <http://www.planalto.gov.br/ccivil_03/_Ato2004-2006/2005/Lei/L11107.htm>. Acesso em: 23 out. 2018.

BRASIL. Emenda Constitucional n ${ }^{\circ}$ 53, de 19 de dezembro de 2006. Dá nova redação aos arts. $7^{\circ}, 23,30,206,208,211$ e 212 da Constituição Federal e ao art. 60 do Ato das Disposições Constitucionais Transitórias. Brasília: Presidência da República, Casa Civil, Subchefia para Assuntos Jurídicos, [2006]. Disponível em: <http://www.planalto.gov.br/ccivil_03/constituicao/Emendas/Emc/ emc53.htm>. Acesso em: 8 out. 2018.

BRASIL. Plano de Desenvolvimento da Educação: razões, princípios e programas. Brasília: MEC, 2007a. Disponível em: <http://portal.mec.gov.br/arquivos/livro/livro.pdf> . Acesso em: 8 maio 2019.

BRASIL. Decreto $\mathbf{n}^{\mathbf{0}} \mathbf{6 . 0 1 7}$, de 17 de janeiro de 2007. Regulamenta a Lei no 11.107, de 6 de abril de 2005, que dispõe sobre normas gerais de contratação de consórcios públicos. Brasília: Presidência da República, Casa Civil, Subchefia para Assuntos Jurídicos, [2007b]. Disponível em: <http://www.planalto.gov.br/ccivil_03/_Ato2007-2010/2007/Decreto/D6017.htm>. Acesso em: 8 maio 2019.

BRASIL. Decreto $\mathbf{n}^{\circ} \mathbf{6 . 0 9 4}$, de 24 de abril de 2007. Dispõe sobre a implementação do Plano de Metas Compromisso Todos pela Educação, pela União Federal, em regime de colaboração com Municípios, Distrito Federal e Estados, e a participação das famílias e da comunidade, mediante programas e ações de assistência técnica e financeira, visando a mobilização social pela melhoria da qualidade da educação básica. Brasília: Presidência da República, Casa Civil, Subchefia para Assuntos Jurídicos, [2007c]. Disponível em: <http://www.planalto.gov.br/ccivil_03/_ato2007-2010/2007/decreto/d6094.htm>. Acesso em: 19 out. 2018.

BRASIL. Emenda Constitucional No 59, de 11 de novembro de 2009. Acrescenta $\int 3^{\circ}$ ao art. 76 do Ato das Disposições Constitucionais Transitórias para reduzir, anualmente, a partir do exercício de 2009, o percentual da Desvinculação das Receitas da União incidente sobre os recursos destinados à manutenção e desenvolvimento do ensino de que trata $\mathrm{O}$ art. 212 da Constituição Federal, dá nova redação aos incisos I e VII do art. 208, de forma a prever a obrigatoriedade do ensino de quatro a dezessete anos e ampliar a abrangência dos programas suplementares para todas as etapas da educação básica, e dá nova redação ao $\int 4^{\circ}$ do art. 211 e ao $\int 3^{\circ}$ do art. 212 e ao caput do art. 214, com a inserção neste dispositivo de inciso VI. Diário Oficial da União: seção 1, Brasília, DF, n. 216, p. 8, 12 nov. 2009.

BRASIL. Resolução No 4, de 13 de julho de 2010. Define Diretrizes Curriculares Nacionais Gerais para a Educação Básica. Diário Oficial da União: seção 1, Brasília, DF, n. 133, p. 824-828, 14 jul. 2010.

BRASIL. Parecer $\mathbf{n}^{\mathbf{0}} \mathbf{9}$, de 30 de agosto de 2011. Análise de proposta de fortalecimento e implementação do regime de colaboração mediante arranjos de desenvolvimento da Educação. Brasília, Ministério da Educação, Conselho Nacional de Educação, [2011a]. Disponível em: 
$<$ http: $/ /$ portal.mec.gov.br/index.php?option $=$ com_docman\&view $=$ download\&alias $=8851$ pceb009-11-pdf\&category_slug=setembro-2011-pdf\&Itemid=30192>. Acesso em: 7 mar. 2019.

BRASIL. Projeto de Lei $\mathbf{n}^{\mathbf{0}}$ 2.417, de 2011. Dispõe sobre Arranjos de Desenvolvimento da Educação (ADE). Brasília: Câmara dos Deputados, [2011b]. Disponível em: <https://www.camara.leg.br/proposicoesWeb/prop_mostrarintegra;jsessionid=E038B1C91541 2184D1A7BDA9BE781995.proposicoesWebExterno1 ?codteor $=924889 \&$ filename $=\mathrm{PL}+2417 / 2$ 011>. Acesso em: 9 nov. 2018.

BRASIL. Decreto $\mathbf{n}^{\circ} \mathbf{7 . 4 8 0}$, de 16 de maio de 2011. Aprova a Estrutura Regimental e o Quadro Demonstrativo dos Cargos em Comissão do Grupo-Direção e Assessoramento Superiores - DAS e das Funções Gratificadas do Ministério da Educação e dispõe sobre remanejamento de cargos em comissão. Brasília: Presidência da República, Casa Civil, Subchefia para Assuntos Jurídicos, [2011c]. Disponível em: <http://www.planalto.gov.br/ccivil_03/_ato20112014/2011/\%20decreto/\%20d7480>. Acesso em: 9 nov. 2018.

BRASIL. Projeto de Lei Complementar $\mathbf{n}^{\mathbf{0}}$ 15, de 2011. Estabelece normas para cooperação entre a União e os Estados, o Distrito Federal e os Municípios, com relação à responsabilidade na gestão pública da educação escolar brasileira. Brasília: Câmara dos Deputados, [2011d]. Disponível em:

$<$ https://www.camara.leg.br/proposicoesWeb/\%20fichadetramitacao?idProposicao $=492957>$.

Acesso em: 9 nov. 2018.

BRASIL. Resolução $\mathbf{n}^{\mathbf{0}}$ 1, de 23 de janeiro de 2012. Dispõe sobre a implementação do regime de colaboração mediante Arranjo de Desenvolvimento da Educação (ADE) como instrumento de gestão pública para a melhoria da qualidade social da educação. Brasília: Ministério da Educação, Conselho Nacional de Educação, Câmara de Educação Básica, [2012a]. Disponível em: $<$ http: $/ /$ portal.mec.gov.br/index.php?option $=$ com_docman\&view $=$ download\&alias $=9816$ rceb001-12\&\%20Itemid=30192>. Acesso em: 7 mar. 2019.

BRASIL. Decreto $\mathbf{n}^{\mathbf{0}} \mathbf{7 . 6 9 0}$, de 2 março de 2012. Aprova a Estrutura Regimental e o Quadro Demonstrativo dos Cargos em Comissão e das Funções Gratificadas do Ministério da Educação. Brasília: Câmara dos Deputados, [2012b]. Disponível em: <https://www2.camara.leg.br/legin/fed/decret/2012/decreto-7690-2-marco-2012-612507publicacaooriginal-135434-pe.html>. Acesso em: 7 mar. 2019.

BRASIL. Resolução $\mathbf{n}^{\circ}$ 1, de 30 de maio de 2012. Estabelece Diretrizes Nacionais para a Educação em Direitos Humanos. Brasília: Ministério da Educação, Conselho Nacional de Educação, Câmara de Educação Básica, [2012c]. Disponível em: <http://portal.mec.gov.br/dmdocuments/rcp001_12.pdf>. Acesso em: 7 mar. 2019.

BRASIL. Portaria $\mathbf{n}^{\mathbf{0}} \mathbf{1 . 2 3 8}$, de 11 de outubro de 2012. Constitui Grupo de Trabalho para elaborar estudos sobre a implementação de regime de colaboração mediante Arranjos de Desenvolvimento da Educação. Brasília: Ministério da Educação, [2012d]. Disponível em: <http://pne.mec.gov.br/images/pdf/Noticias/\%20Portaria_\%201238_\%202012_GT_ADE_co nsolidado.pdf $>$. Acesso em: 7 out. 2018.

BRASIL. Relatório de Gestão do Exercício de 2012. Brasília: MEC, SASE, 2012d. Disponível em: 
Arranjos de Desenvolvimento da Educação (ADEs) como estratégia de atuação do setor privado...

$<$ http: / $/$ portal.mec.gov.br/index.php?option $=$ com_docman\&view $=$ download\&alias $=14261$ relatorio-gestao-da-sase-exercicio-2012-pdf\&Itemid=30192>. Acesso em: 7 out. 2018.

BRASIL. Portaria $\mathbf{n}^{\mathbf{0}}$ 1, de 19 de fevereiro de 2013. Brasília, Gabinete do Ministro, 2013. p. 4. Disponível

em:

<http://pne.mec.gov.br/images/pdf/publicacoes/Anexos_do_Relatorio_GT_ADE_jul_15.pdf >. Acesso em: 24 nov. 2019.

BRASIL. Relatório de Gestão do Exercício de 2013. Brasília: MEC/SASE, 2014a. Disponível em:

$<$ http://portal.mec.gov.br/index.php?option $=$ com_docman\&view $=$ download\&alias $=15990$ relatorio-gestao-exercicio-2013-sase-pdf\&Itemid=30192 > . Acesso em: 9 out. 2018.

BRASIL. Lei No 13.005, de 25 de junho de 2014. Aprova o Plano Nacional de Educação - PNE e dá outras providências. Diário Oficial da União: seção 1, Brasília, DF, n. 120-A, edição extra, p. 1-7, 26 jun. 2014b.

BRASIL. Projeto de Lei Complementar $\mathbf{n}^{\mathbf{0}}$ 413, de 2014. O presente Projeto de Lei Complementar visa responder especificamente às disposições do artigo 23 da Constituição Federal, acelerada, agora, pela recente sanção da Lei no 13.005/2014 que estabelece o Plano Nacional de Educação e dá outras providências. Brasília: Câmara dos Deputados, [2014c]. Disponível em: $<$ https://www.camara.leg.br/proposicoesWeb/fichadetramitacao?idProposicao $=620859>$.

Acesso em: 28 ago. 2018.

BRASIL. Relatório Final do GT-ADE. Brasília: MEC, 2015a. Disponível em: $<$ http://pne.mec.gov.br/images/pdf/publicacoes/Relatorio_GT_ADE_jul_15.pdf $>$. Acesso em: 18 nov. 2018.

BRASIL. Portaria n ${ }^{\mathbf{0}}$ 7, de 8 de janeiro de 2015. Brasília, Gabinete do Ministro, 2015b. p. 6. Disponível em: <http://pne.mec.gov.br/images/pdf/publicacoes/Anexos_do_Relatorio_GT_ADE_jul_15.pdf >. Acesso em: 24 nov. 2019.

BRASIL. Instituir um Sistema Nacional de Educação: agenda obrigatória para o país. Brasília, SASE/MEC, 2015c. Disponível em: <http://pne.mec.gov.br/images/pdf/SNE_junho_2015.pdf>. Acesso em: 9 out. 2018.

BRASIL. Emenda Constitucional N 95, de 15 de dezembro de 2016. Altera o Ato das Disposições Constitucionais Transitórias, para instituir o Novo Regime Fiscal, e dá outras providências. Diário Oficial da União: seção 1, Brasília, DF, n. 241, p. 2-3, 16 dez. 2016 a.

BRASIL. Prestação de contas ordinária anual. Relatório de Gestão Consolidado Ministério da Educação Exercício 2015. Brasília: MEC, 2016b. Disponível em: <http://portal.mec.gov.br/docman/\%20outubro-2016-pdf/49921-rg-fies-2015-pdf/file>. Acesso em: 27 out. 2018.

BRASIL. Decreto $\mathbf{n}^{\mathbf{0}} \mathbf{9 . 0 0 5}$, de 14 de março de 2017. Aprova a Estrutura Regimental e o Quadro Demonstrativo dos Cargos em Comissão e das Funções de Confiança do Ministério da Educação, remaneja cargos em comissão e substitui cargos em comissão do Grupo-Direção e Assessoramento Superiores - DAS por Funções Comissionadas do Poder Executivo - FCPE. Brasília: Presidência 
da República, Casa Civil, Subchefia para Assuntos Jurídicos, [2017a]. Disponível em: <http://www.planalto.gov.br/ccivil_03/_ato2015-2018/2017/decreto/D9005.htm>. Acesso em: 3 fev. 2019.

BRASIL. Projeto de Lei Complementar $n^{\circ} 448$, de 2017. Regulamenta a cooperação federativa na área da educação, com base no parágrafo único do art. 23 da Constituição Federal [...]. Brasília: Câmara dos Deputados, 2017b. Disponível em: <http://www.camara.gov.br/proposicoesWeb/prop_mostrarintegra?codteor=1626054\&filenam $\mathrm{e}=$ Tramitacao-PLP\%20+413/2014>. Acesso em: 3 fev. 2019.

BRASIL. Parecer do Relator. Dep. Glauber Braga (PSOL-RJ) ao Projeto de Lei Complementar no 413, de 2014 (apenso o PLP nº448/17). Brasília: Câmara dos Deputados, 2017c. Disponível em: Disponível em: <http://www.camara.gov.br/\%20proposicoes $\% 20 \mathrm{Web} /$ prop_mostrarintegra?codteor $=1636417$ \&filename=Tramitacao-PLP+413/2014>. Acesso em: 23 jan. 2019.

BRASIL. [Constituição (1988)]. Constituição da República Federativa do Brasil. Brasília: Supremo Tribunal Federal, Secretaria de Documentação, 2018. Atualizada até a EC n. 99/2017.

BRASIL. Lei de Diretrizes e Bases da Educação Nacional - Lei n. 9.394, de 20 de dezembro de 1996. Atualizada até a Lei n. 13.868, de 3 de setembro de 2019. Brasília: Presidência da República, Casa Civil, Subchefia para Assuntos Jurídicos, [2019a]. Disponível em: <http://www.planalto.gov.br/ccivil_03/leis/19394.htm>. Acesso em: 5 out. 2019.

BRASIL. Câmara dos Deputados. Ficha de tramitação do Projeto de Lei n. 2.417/2011: Requerimento $\mathrm{n}^{\circ}$, de 2019. Brasília: Câmara dos Deputados, 2019b. Disponível em: $<$ https://www.camara.leg.br/proposicoesWeb/prop_mostrarintegra;jsessionid=AD9CBB83781 3821 A28BA64FF8F6116A8.proposicoesWebExterno2?codteor $=1824437 \&$ filename $=$ Tramitacao -PL+2417/2011>. Acesso em: 1 dez. 2019.

CARVALHO, E. J. G. A educação básica brasileira e as novas relações entre o Estado e os empresários. Revista Retratos da Escola, Brasília, v. 11, n. 21, p. 525-541, jul./dez. 2017. DOI: http://dx.doi.org/10.22420/rde.v11i21.800

CARVALHO, E. J. G. Arranjos de Desenvolvimento da Educação (ADEs): instrumento de soluções colaborativas para a educação ou uma nova estratégia de expansão e de controle do mercado educacional? Currículo sem Fronteiras, v. 18, n. 1, p. 103-128, jan./abr. 2018.

CARVALHO, E. J. G. Arranjos de Desenvolvimento da Educação (ADEs): nova oportunidade de negócios educacionais para as organizações do setor privado. Revista Brasileira de Política e Administração da Educação, Goiás, v. 35, n. 1, p. 57-76, jan./abr. 2019. DOI: https://doi.org/10.21573/vol1n12019.93095

CHESNAIS, F. A mundialização do capital. São Paulo: Xamã, 1996.

CURY, C. A. J. Do sistema de colaboração recíproca. In: ABRÚCIO, F. L.; RAMOS, M. N. (orgs.). Regime de colaboração e associativismo territorial: arranjos de desenvolvimento da Educação. São Paulo: Moderna, 2012. p. 31-44.

HARVEY, D. O neoliberalismo: história e suas implicações. São Paulo: Loyola, 2011. 
Arranjos de Desenvolvimento da Educação (ADEs) como estratégia de atuação do setor privado...

INEP. Notas Estatísticas - Censo Escolar 2018. Brasília: INEP, MEC, 2018. Disponível em: <http://download.inep.gov.br/educacao_basica/censo_escolar/notas_estatisticas/2018/notas_e statisticas_censo_escolar_2018.pdf>. Acesso em: 23 jan. 2019.

LIMA, L. Privatização lato sensu e impregnação empresarial na gestão da educação pública. Currículo sem Fronteiras, v. 18, n. 1, p. 129-144, jan./abr. 2018.

MAIA, M. H. Regime de Colaboração no PNE: antecedentes, propostas, perspectivas e desafios. Brasília: Câmara dos Deputados, 2017. Disponível em: <http://www2.camara.leg.br/atividade-legislativa/\%20estudos-e-notas-tecnicas/areas-daconle/tema11/regime-de-colaboracao-no-pne-antecedentes-propostas-perspectivas-e-desafios $>$. Acesso em: 3 jun. 2019.

MANDELLI, M. Municípios formam 'minirredes' para melhorar educação. O Estado de S. Paulo, 2012. Disponível em: <http://www.estadao.com.br/noticias/geral,municipios-formamminirredes-para-melhorar -educacao-imp-,831961>. Acesso em: 11 out. 2018.

MOTTA, V. C; ARGOLlO, J. Em curso um Sistema Nacional De Educação nos moldes dos Arranjos de Desenvolvimento da Educação. Revista Contemporânea de Educação, Rio de Janeiro, v. 11, n. 22, p. 281-300, 2016. DOI: https://doi.org/10.20500/rce.v11i22.4143.

NEWMAN, J.; CLARKE, J. Gerencialismo. Educação \& Realidade, Porto Alegre, v. 37, n. 2, p. 353-381, 2012.

OLIVEIRA, C.; GANZELI, P. Relações intergovernamentais na educação: fundos, convênios, consórcios públicos e arranjos de desenvolvimento da educação. Educação \& Sociedade, Campinas, v. 34, n. 125, p. 1031-1047, out./dez. 2013. DOI: http://dx.doi.org/10.1590/S0101$\underline{73302013000400002}$

PERONI, V. M. V. Implicações da relação público-privada para a democratização da educação. In: PERONI, V. M. Diálogos sobre as redefinições no papel do Estado e nas fronteiras entre o público e o provado na educação. São Leopoldo: Oikos, 2015. p. 15-34.

PERONI, V. M. V. Múltiplas formas de materialização do privado na educação básica pública no Brasil: sujeitos e conteúdo da proposta. Currículo sem Fronteiras, v. 18, n. 1, p. 212-238, jan./ abr. 2018a.

PERONI. V. M. V. Implicações da relação público-privada para a democratização da educação. In: PERONI, V. M. V.; LIMA, P. V.; KADER, C. R. (Orgs.). Redefinições das fronteiras entre público e privado: implicações para a democratização da educação. São Leopoldo: Oikos, 2018b. p. $93-104$.

RAMOS, M. N. Arranjos de Desenvolvimento da Educação. In: ABRÚCIO, F. L.; RAMOS, M. N. (Orgs.). Regime de colaboração e associativismo territorial: arranjos de desenvolvimento da Educação. São Paulo: Moderna, 2012. p. 67-84.

RIKOWSKI, G. Privatização em educação e formas de mercadoria. Retratos da Escola, Brasília, v. 11, n. 21, p. 393-413, jul./dez. 2017. DOI: http://dx.doi.org/10.22420/rde.v11i21.810 
RIKOWSKI, G. Deturpações: notas críticas sobre Mercadorias e Educação. Currículo sem Fronteiras, v. 18, n. 1, p. 269-283, jan./abr. 2018.

SGUISSARDI, V. Educação superior no Brasil: democratização ou massificação mercantil? Educação \& Sociedade, Campinas, v. 36, n. 133, p. 867-889, out./ dez. 2015. DOI: http://dx.doi.org/10.1590/ES0101-73302015155688

Recebido em 10/09/2019

Versão corrigida recebida em 20/11/2019

Aceito em 22/11/2019

Publicado online em 04/12/2019 